\title{
Related Party Cooperation, Ownership Structure and Value Creation
}

\author{
Zhi-hong Song ${ }^{1}$, Xiao-fei Che ${ }^{2}$, Yan-xin Guo ${ }^{3}$ \\ ${ }^{1}$ Institute of Management and Decision, Shanxi University, Taiyuan, China \\ ${ }^{2}$ School of Economics and Management, Shanxi University, Taiyuan, China \\ ${ }^{3}$ School of Mathematical Sciences, Shanxi University, Taiyuan, China
}

\section{Email address:}

songzhihong@sxu.edu.cn (Zhi-hong Song)

\section{To cite this article:}

Zhi-hong Song, Xiao-fei Che, Yan-xin Guo. Related Party Cooperation, Ownership Structure and Value Creation. American Journal of Theoretical and Applied Business. Vol. 2, No. 2, 2016, pp. 8-12. doi: 10.11648/j.ajtab.20160202.11

Received: September 7, 2016; Accepted: October 7, 2016; Published: October 28, 2016

\begin{abstract}
Taking the 141 related party cooperation announcements by Chinese listed companies from January 2001 to December 2013 as the sample, the article investigates the impact of the focal firms' ownership structure and relative characteristics of related parties on the focal firms' value creation. The empirical results indicate that ownership concentration negatively affect the value creation, while equity restriction has no influence on the focal firms' value creation. The related party's relative scale plays a significantly positive role on the focal firms' value creation, while the related party's relative associated relationship is negatively related to the focal firms' value creation. The article contributes to the current literature by investigating whether the governance mechanism of listed companies could create value for the focal firms under the background of related party cooperation, and providing empirical evidence about the influence of ownership structure and relative characteristics of related party on the focal firms' value creation.
\end{abstract}

Keywords: Related Party Cooperation, Ownership Concentration, Equity Restriction, Value Creation

\section{Introduction}

A related-party cooperation is a business deal or arrangement between two parties who are joined by a special relationship prior to the deal. Related-party cooperation is a common occurrence in the business marketplace. Companies often seek business deals with entities to which they are familiar with or have been referred to through past relationships. Previous theories provide contradictory views on the value creation effects of related party cooperation. On the one hand, transaction cost theory suggests that related party cooperation help firms reduce transaction cost and improve value of the focal firms. On the other hand, according to agency theory, the special relationship inherent between the involved parties creates potential conflicts of interest, which can result in actions that benefit the people involved as opposed to the shareholders. In addition, large shareholders may appropriate the benefits of the listed companies to those related parties which they have a stake and thus may be detrimental to the value of the firms. Therefore, majority shareholders may damage the interests of the firms by tunneling activities through related party transactions directly or indirectly, which may dampen the optimal allocation of resources in the capital market and the sustainable development of capital market and social economy. Related party cooperation positively affects the firms' future profitability but negatively affect the short-term profit margins. The reason may be that the profitability brought by related party cooperation may provide confidence for investors, and those cooperation based on insider information can promote stock return to its real value, which is beneficial to the future development of the firm. However, Cheung et al. [1] examine a sample of 328 filings of "connected transactions" between Hong Kong listed companies and their controlling shareholders and their findings indicate that firms earn significant negative excess returns both around the initial announcement of the connected transactions and during the 12-month period following the announcement. Besides, their findings also show that excess returns are significantly negatively related to related party transactions compared to other transactions. Djankov et al. [2] suggest that 
related party cooperation may provide opportunity to get cash from listed companies by tunneling.

As for research on the influence of ownership structure on the firms' value creation, there are no consistent research conclusions. Demsetz \& Villalonga [3] find that there is no significant relationship between ownership concentration and firm performance. Shleifer \& Vishny [4] propose that there is a positive relationship between ownership concentration and firm value. Liu \& Ho [5] find that the way of transferring interests varies with the equity ownership structure. If the controlling shareholders hold a higher proportion of shares or the share is more dispersed, then the motivation of the controlling shareholders to engage in tunneling activities is weak. The large shareholders tend to tunnel by means of equity transfer, assurance and appropriation only when they act as a controlling shareholder of the listed company. Xu et al. [6] find that there is a significant positive relationship between ownership concentration and operating performance and the relationship holds for different types of controlling shareholders. Besides, she attributes the above differences to the different performance measures, the endogenity of ownership structure, and the methods regarding the category of ownership. Liu \& Gao [7] show that the difference in performance is not significant for firms with high degree of equity restriction and ownership concentration, that is, equity restriction has no significant influence on the performance of the company.

This article contributes to the current literature in the following two ways: First, previous research has been conducted on the developed countries, literature on the related party cooperation under the Chinese background is still scarce. Therefore, it is desperately needed to examine what factors could enhance value creation for focal firms in the Chinese context. Second, it is the first time that this article not only investigates whether cooperation between the related parties would create value for focal firms, but also provides empirical evidence about the influence of ownership structure and relative characteristics of related party on the focal firms' value creation.

The rest of the paper is organized as follows. The following section describes the sample, data sources and variable measurement. Section 3 empirically investigates the relationship between the ownership structure and the relative characteristics of the related party on the value creation of the focal firms. Section 4 summarizes the conclusions and provides the limitations and future research directions.

\section{Sample, Data Sources, and Variable Measurement}

\subsection{Sample and Data Sources}

All the data in this paper are based on the CSMAR database. The sample selection procedures are as follows: First of all, we retrieve Chinese A-share listed companies with related party transactions in information technology industry from "Listed company related transaction database" from January 1, 2001 to December 31, 2013, which results in 184 listed companies. Second, we select 4 categories of related party transactions, which include equity transactions, cooperative projects, technology development and research, and licensing agreements, and there are 50 listed companies altogether. For the above categories of related transactions, in order to avoid other miscellaneous events which may influence the cooperation between firms on the value creation, we drop out companies with incomplete data according to the date of the announcements of the related party transactions and we obtain 141 related party cooperation announcements as our final sample.

Table 1 shows the sample distribution by types of cooperation and by the relationship between related parties. Panel A presents the distribution results based on the types of related party cooperation. The number of announcements for equity transactions is $75(53.19 \%)$, followed by licensing agreements with 28 announcements 28 (19.86\%). Panel B shows the sample distribution by the relationship between related parties, in which the parent company of the listed companies accounts for $76.60 \%$, followed by subsidiary company of the listed companies $(11.35 \%)$.

\subsection{Variable Measurement}

\subsubsection{Dependent Variable}

Table 1. Sample distribution

\begin{tabular}{lll}
\hline \multicolumn{3}{l}{ Panel A Sample distribution by types of cooperation } \\
\hline Types of cooperation & $\begin{array}{l}\text { Number of } \\
\text { announcements }\end{array}$ & Percentage \\
\hline $\begin{array}{l}\text { Equity transactions } \\
\text { Cooperative projects }\end{array}$ & 75 & 53.19 \\
$\begin{array}{l}\text { Technical development and } \\
\text { research }\end{array}$ & 14 & 9.93 \\
$\begin{array}{l}\text { Licensing agreements } \\
\text { Total }\end{array}$ & 24 & 17.02 \\
$\begin{array}{l}\text { Panel B Sample distribution by the relationship between related parties } \\
\text { Relationship between related } \\
\text { parties }\end{array}$ & Number of & 19.86 \\
$\begin{array}{l}\text { Parent company of the listed } \\
\text { companies }\end{array}$ & announcements & Percentage \\
$\begin{array}{l}\text { Subsidiary company of the } \\
\text { listed companies }\end{array}$ & 108 & 76.60 \\
$\begin{array}{l}\text { Investors with significant } \\
\text { influence }\end{array}$ & 16 & 11.35 \\
$\begin{array}{l}\text { Joint ventures of the listed } \\
\text { companies }\end{array}$ & 5 & 3.55 \\
$\begin{array}{l}\text { Others } \\
\text { Total }\end{array}$ & 10 & 7.09 \\
\hline
\end{tabular}

Based on Shleifer \&Vishny [4] and McConnell \& Servaes [8], we choose Tobin's Q as a measure of the value of the focal firm. Tobin's $Q$ is defined as the ratio of the market value of the firm to the replacement value of its assets, and the market value of a firm is determined by the stock prices. If Tobin's $\mathrm{Q}>1$, it indicates that investors are optimistic about the future growth opportunities of the focal firms, and larger Tobin's Q means more growth opportunities and more value creation of the focal firms. Therefore, Tobin's Q can reflect the future performance and long-term profitability of the firm. In this 
article, the market value of a firm is represented by the sum of market value of the listed company and the market value of the net debt, in which we use net assets to replace non tradable equity market value and the book value of the total assets to replace the replacement cost of the asset because of the data availability.

\subsubsection{Independent Variables}

We choose the ownership concentration and equity restriction as proxies for ownership structure. Equity concentration is measured with $\mathrm{H}$-index, which is the sum of squares of the top five shareholders' shareholding ratio, while equity restriction is measured with Z-index which is the ratio of the shareholding of the largest shareholder to that of the second largest shareholder. The greater the Z-index value, the greater the difference of shareholding between the largest shareholder and the second largest shareholder and the more obvious of the control advantages of the largest shareholder. On the contrary, the smaller the Z-index, the weaker restriction ability of other shareholders to the largest shareholder, thus Z-index can act as a proxy for the largest shareholder's ability to control the company.

As for relative characteristics of the related party, we use the following three measures: geographical relationship (DMGR), relative size (DMRS) and relative associated relationship (DMRR). The DMGR dummy equals zero for partners that operate in same geographical distance, and one otherwise. The DMRS dummy equals one if the ratio of the registered capital of the listed company to related party is greater than one, and zero otherwise. If both sides of the related party cooperation have other associated relationship, for example, listed company have a parent company, then it is not beneficial to the value creation of the focal firms, thus we use DMRR to assess the tunneling activities of the parent company to the listed company. DMRR dummy equals one if related party is a subsidiary of listed companies, and zero otherwise.

\subsubsection{Control Variables}

Previous studies suggest other factors also affect the wealth creation of inter-firm cooperation. Thus, we controlled for the effects of other prospective variables in this study. Specifically, the size of the focal firm, debt ratio and return on equity are used as control variables to eliminate the impact of such factors.

Table 2. Description of the variables in the study.

\begin{tabular}{|c|c|c|}
\hline \multicolumn{2}{|l|}{ Variables } & Description \\
\hline \multicolumn{2}{|c|}{ Value creation(Tobin's Q) } & $\begin{array}{l}\text { The ratio of the market value of the firm to the replacement value of its assets, where } \\
\text { the market value of assets is estimated as the book value of assets minus the book value } \\
\text { of common equity plus the market value of common equity and the market value of non } \\
\text { tradable equity is replaced by net assets. }\end{array}$ \\
\hline \multirow{3}{*}{$\begin{array}{l}\text { Characteristics of } \\
\text { ownership structure }\end{array}$} & Ownership concentration(H-index $)$ & Sum of squares of the top five shareholders' sharholding ratio \\
\hline & Equity restriction (Z-index) & The ratio of the proportion of the largest shareholder and the second largest shareholder. \\
\hline & Geographical relationship(DMGR) & $\begin{array}{l}\text { The DMGR dummy equals zero for partners that operate in same location, and one } \\
\text { otherwise }\end{array}$ \\
\hline \multirow{3}{*}{$\begin{array}{l}\text { Relative } \\
\text { characteristics of the } \\
\text { related party }\end{array}$} & Relative size(DMRS) & $\begin{array}{l}\text { The DMRS dummy equals one if the ratio of the registered capital of the listed } \\
\text { company to related party is greater than one, and zero otherwise }\end{array}$ \\
\hline & Relative associated relationship(DMRR) & $\begin{array}{l}\text { DMRR dummy equals one if related party is a subsidiary of listed companies, and zero } \\
\text { otherwise. }\end{array}$ \\
\hline & $\begin{array}{l}\text { Related party } \\
\text { transactions(DMRC1 DMRC3) }\end{array}$ & $\begin{array}{l}\text { Three dummy variables are set for types of relative cooperation(equity transactions, } \\
\text { cooperative projects, technology development and research and licensing contracts) }\end{array}$ \\
\hline \multicolumn{2}{|c|}{ Size(LNSIZE) } & Logarithm of the total assets. \\
\hline Debt ratio(LEVERAC & & Ratio of total liabilities to total assets \\
\hline
\end{tabular}

\section{Empirical Results and Discussion}

\subsection{Descriptive Statistics and Correlation Analysis}

Table 3 presents the means, standard deviations and correlation analysis on the dependent variables, independent variables and control variables. Table 3 shows that the mean of Tobin's Q is greater than one, which implies the future growth opportunities of focal firms are relatively optimistic. The mean sum of squares of the top five shareholders' shareholding ratio is 0.177 , which implies the focal firm is relatively concentrated in equity. The mean ratio of the proportion of the largest shareholder to the second largest shareholder is 18.796 , which implies the other shareholders' restriction to the largest shareholder is relatively weak. As for the relative characteristics of the related party, the mean value of the relative geographical distance between the focal firm and their related party is 0.18 , which implies most of them are operating in the same city. The mean value of relative size is 0.57 and it implies that focal firm's are roughly the same as the related party. At last, the mean value of relative relationship is 0.11 , which is a small value and implies that there are few related-parties which are subsidiaries of listed companies.

Since there are many explanatory variables which are included in the model, multicollinearity diagnosis is used before regression analysis. The diagnosis results show that variance inflation factor is well below the threshold level. In addition, the correlation coefficients between the explanatory variables are below 0.5 , so there is no serious problem of multicollinearity. 
Table 3. Means, standard deviations and correlation matrix.

\begin{tabular}{|c|c|c|c|c|c|c|c|c|c|c|c|c|c|c|}
\hline & Mean & $\begin{array}{l}\text { Standard } \\
\text { deviation }\end{array}$ & Tobin's Q & H-index & Z-index & DMGR & DMRS & DMRR & DMRC1 & DMRC2 & DMRC3 & ROE & Leverage & Lnsize \\
\hline Tobin's Q & 1.873 & 1.017 & 1 & & & & & & & & & & & \\
\hline H-index & 0.177 & 0.112 & $-0.209^{*}$ & 1 & & & & & & & & & & \\
\hline Z-index & 18.796 & 31.213 & $-0.204 *$ & $0.390 * *$ & 1 & & & & & & & & & \\
\hline DMGR & 0.180 & 0.383 & -0.026 & $-0.204^{*}$ & -0.131 & 1 & & & & & & & & \\
\hline DMRS & 0.570 & 0.496 & $0.282 * *$ & $-0.281 * *$ & 0.004 & $0.174 *$ & 1 & & & & & & & \\
\hline DMRR & 0.110 & 0.318 & -0.022 & -0.056 & -0.111 & $0.244 * *$ & $0.308 * *$ & 1 & & & & & & \\
\hline DMRC2 & 0.100 & 0.300 & -0.054 & 0.017 & -0.055 & -0.030 & 0.142 & $0.180^{*}$ & $-0.354 * *$ & 1 & & & & \\
\hline DMRC3 & 0.200 & 0.400 & -0.110 & 0.042 & $0.341 * *$ & 0.141 & 0.141 & $-0.178 *$ & $-0.495 * *$ & -0.165 & 1 & & & \\
\hline ROE & 0.026 & 0.041 & $0.185^{*}$ & 0.055 & $0.296^{* *}$ & -0.110 & 0.061 & 0.094 & $0.192^{*}$ & -0.079 & 0.012 & 1 & & \\
\hline Leverage & 0.452 & 0.167 & $-0.249 * *$ & $-0.171 *$ & 0.005 & -0.075 & $-0.236 * *$ & $-0.166^{*}$ & 0.032 & -0.011 & 0.007 & 0.085 & 1 & \\
\hline Lnsize & 2.171 & 1.164 & $-0.230 * *$ & -0.019 & $0.184 *$ & 0.069 & $-0.177 *$ & -0.143 & 0.114 & -0.074 & $0.260 * *$ & $0.176^{*}$ & $0.457 * *$ & 1 \\
\hline
\end{tabular}

*.Significant at the 0.05 level (Two-tailed test).

**.Significant at the 0.01 level (Two-tailed test).

\subsection{Regression Analysis and Discussion}

In order to accurately investigate the effects of ownership structure and the relative characteristics of the related party on the value creation of the focal firms, we build up four multivariate regression models with Tobin's $Q$ as the dependent variable. Model 1 includes only the control variables. Model 2 and Model 3 add the independent variable of ownership structure and related party's relative characteristic respectively, while Model 4 includes all the variables. The results are shown in Table 4.

Table 4. Results of the regression analyses.

\begin{tabular}{lllll}
\hline Variable & Tobin's Q & & & \\
\hline & Model1 & Model2 & Model3 & Model4 \\
\hline H-index & & $-2.841^{* * *}$ & & $-2.254^{* *}$ \\
Z-index & & -0.001 & & -0.001 \\
DMGR & & & -0.137 & -0.213 \\
DMRS & & & $0.898^{* * *}$ & $0.755^{* * *}$ \\
DMRR & & & $-0.660^{* *}$ & $-0.608^{* *}$ \\
DMRC1 & & & 0.116 & 0.162 \\
DMRC2 & & & -0.234 & -0.150 \\
DMRC3 & & & -0.237 & -0.146 \\
ROE & $7.934 * * *$ & $7.574 * * *$ & $7.728 * * *$ & $7.401 * * *$ \\
Leverage & $-1.462 * *$ & $-1.750 * * *$ & $-1.185 *$ & $-1.487 * *$ \\
Lnsize & $-0.146 *$ & -0.117 & -0.085 & -0.077 \\
R & 0.229 & 0.299 & 0.333 & 0.373 \\
Adjusted-R & & & 0.281 & 0.313 \\
Durbin-Watson & 0.206 & 0.268 & 2.030 & 2.031 \\
F--statistic & 1.991 & 1.983 & 6.439 & 6.193 \\
Prob(F-statistic) & 9.998 & 9.466 & 0.000 & 0.000 \\
\hline
\end{tabular}

Note. "***”, “**” and "*" represent $1 \%, 5 \%$ and $10 \%$ significance levels using a two-tailed test, respectively.

In general, the adjusted coefficients of determination in Model 1, Model 2, Model 3, and Model 4 are 0.206, 0.268, 0.281 , and 0.313 respectively, which implies that there is reasonable goodness of fit between regression models and data. The Prob (F-statistic) is 0.000 , which further supports general linear relationship between dependent and independent variables. Model 2 and Model 3 greatly improves the degree of fitness because we gradually include the variable of ownership structure and relative characteristics of the related party. As we can see from
Model1 to Model4, the regression coefficients and the significance level of the four models are relatively consistent and stable. Thus, we mainly discuss the results of regression analysis based on Model4.

Model 2 shows that the impact of ownership concentration on the value creation of focal firms is significantly negative $(\beta=-2.841, p=0.000)$ and it is remain significantly negative after adding the variables of relative characteristics of the related party into the model $(\beta=-2.254, p=0.012)$, thus the ownership concentration has a significantly negative impact on the value creation for the focal firms. Our result is consistent with Leech \& Leahy [9] and Mudambi \&Nicosia [10], who find that controlling shareholders could appropriate the value of focal firms by private or unfair related party transactions.

Different from $\mathrm{Xu}$ et al. [6], our results suggest that equity restriction has no significant impact on the value creation of focal firms, and the reason may be that the first major shareholder and the second major shareholder share common interests and are even controlled by the same ultimate owner. In Model 4, we add the variables of the characteristics of related parties, and the results show that the relative geographical distance between the focal firms and the related parties have no significant influence on the value creation of the focal firms. Our results is consistent with Crutchley \& Hansen [11]. The coefficient of relative size is $0.755(p=0.000)$ and is still significantly positive after controlling the effect of ownership structure, which is similar to McConnell \& Nantell [12] for size effect and consistent with Crutchley \& Hansen [11]. The coefficient of relative associated relationship is significantly negative $-0.608(\mathrm{p}=0.032)$, which means that the related party transactions would not create value for focal firms if related party is subsidiaries of the list company. Prior studies have shown that if the shareholding ratio of controlling shareholder keeps the same, then there will be related party assurance between listed companies and subsidiaries, which will provide guarantee in disguised form for controlling shareholders and their tunneling behavior to listed companies. Our results are different from previous literature $[13,14]$. The reason may be that the controlling shareholder of the focal firm has become an important supporter of the related party transactions and appropriates the value creation of parent company behind the 
scenes. If the subsidiary wish to cooperate with related parties rather than dominated by its parent company, then it may negatively affect the value creation of the listed companies.

\section{Conclusion}

Taking the 141 related party cooperation announcements by Chinese A-share listed companies from January 2001 to December 2013 as the sample, the paper investigates the impact of the focal firms' ownership structure and relative characteristics of related parties on the focal firms' value creation. The empirical results indicate that ownership concentration negatively affect the value creation, while equity restriction has no influence on the focal firms' value creation. The related party's relative scale plays a significantly positive role on the focal firms' value creation, while the related party's relative associated relationship is negatively related to the focal firms' value creation. The paper contributes to the current literature by investigating whether the governance mechanism of listed companies would create value for the focal firms under the background of related party cooperation in the Chinese context, and investigating the effects of the relative characteristics of the related party on the focal firms' value creation.

Of course, this study suffers from some limitations that future research should overcome. First, Tobin's Q is used for the measure of value creation for focal firms. Tobin's $Q$ can reflect investors' expectations about future profitability of firms, however, due to the restricted sale of shares for some listed companies in Chinese A-share market, this measure cannot be accurately figured out. Second, compared with the excess returns or wealth effects after the announcement date of the related party cooperation, we mainly focus on the long-term effects of characteristics of ownership structure and related parties on the value creation of firms. The event-study method can be applied to investigate the wealth effect of the related party cooperation, in other words, future research should pay more attention to the short-term effect of the value creation.

\section{References}

[1] Cheung, Y. L., Rau, P. R. and Stouraitis, A. (2006).Tunneling, propping and expropriation: Evidence from connected party transactions in Hong Kong. Journal of Financial Economics. 82(2): 343-386.
[2] Djankov, S., La Porta, R., Lopezde-Silanes, F. and Shleifer, A. (2008). The law and Economics of self dealing. Journal of Financial Economics, 88(3): 430-465.

[3] Demsetz, H., Villalonga, B. (2001). Ownership structure and corporate performance. Journal of Corporate Finance, 7(3): 209-233.

[4] Shleifer, A. and Vishny, R. (1986). Large shareholders and corporate control. Journal of Political Economy, 94(3): 461-488.

[5] Liu, F. and Ho, J. (2004). Ownership structure and substantial shareholders' choice in interest realizing methods: Tentative study on tunneling in Chinese capital market. China Accounting Review, 2(1): 141-158.(In Chinese).

[6] Xu, L., Xin, Y. and Chen, G. (2006). Ownership concentration, outside blockholders, and operating performance: Evidence from China's listed companies. Economic Research Journal,41(1): 90-100. (In Chinese).

[7] Liu, Y.and Gao, Y. (2007). The relationship between ownership restriction and corporate performance of listed companies in China. Journal of Sun Yatsen University (Social Science Edition), 47(4):102-108. (In Chinese).

[8] McConnell, J. and Servaes, H. (1990). Additional evidence on equity ownership and corporate value. Journal of Financial Economics, 27(2): 596 - 612.

[9] Leech, D. and Leahy, J. (1991). Ownership structure, control type classifications and the performance of large British companies. The Economic Journal, 101(409):1418-1437.

[10] Mudambi, R., and Nicosia, C. (1998).Ownership structure and firm performance: Evidence from the UK financial services industry. Applied Financial Economics, 8:175-180.

[11] Crutchley, C., Guo, E. and Hansen, R. (1991). Stockholder benefits from Japanese-U.S. joint ventures. Financial Management, 20(4): 22-30.

[12] McConnell, J. and Nantell, T. (1985). Corporate combinations and common stock returns: the case of joint ventures. Journal of Finance, 40(2): 519-536.

[13] Liu, S. (2007). The paradox of private benefits of control and excessive benefits of control: A new theoretical explanation of large shareholders' expropriation of small ones. Economic Research Journal, (2): 85-96. (In Chinese).

[14] Rao, Y., Zhang, Y. and Peng, D. (2008).Holding proportion, over guarantee and tunneling: evidence from the guarantee of Chinese listed companies to their subsidiaries. Nankai Business Review, 11(1): 31-38. (In Chinese). 